\section{ІМЕРСИВНІСТЬ ЯК МИСТЕЦЬКА СТРАТЕГІЯ ПОЧАТКУ ХХІ СТОЛІТТЯ (АНАЛІЗ ТЕАТРАЛЬНОГО ДОСВІДУ ТА ЙОГО ФІЛОСОФСЬКИХ ПІДВАЛИН)}

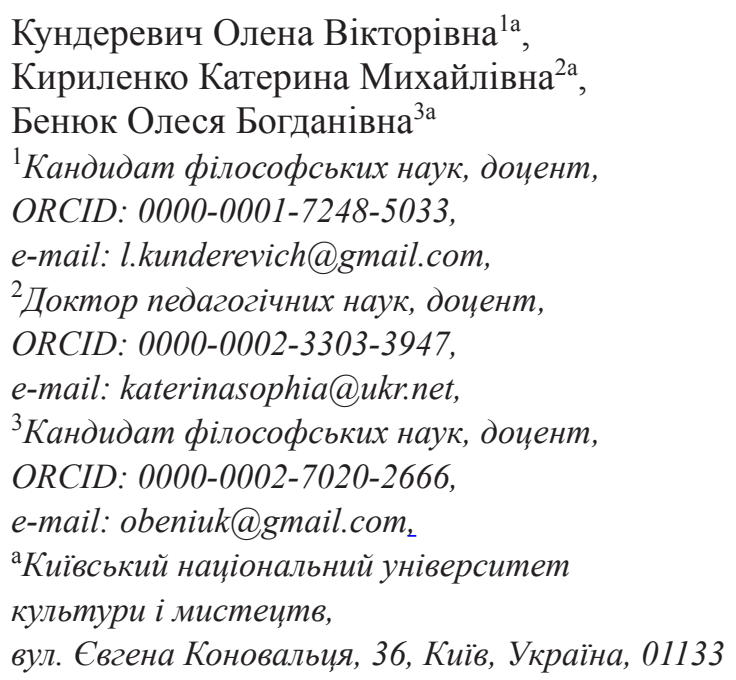

Мета статті - розкрити полісемантичність поняття «імерсивність»; проаналізувати наявний імерсивний досвід сучасного театрального мистецтва в контексті реалізації ним новітніх мистецьких стратегій; визначити та опрацювати теоретичне та методологічне підгрунтя імерсивності як нового поняття в сучасній естетиці, філософії мистецтва та філософії культури. Методологію дослідження сформували методи емпіричного (спостереження, порівняння, моніторингу) та теоретичного дослідження (міждисциплінарного аналізу, конкретизації, абдуктивного міркування). Висновки. На основі поєднання емпіричного та теоретичного методів здійснено аналіз трансформаційного потенціалу імерсивних практик. Надано ширшу експлікацію таким поняттям, як «імерсивність», «імерсивні практики», «імерсивний театр». Встановлено теоретичні засади дослідження культурфілософських основ імерсивності. 3'ясовано, що імерсивність є способом сприйняття, який визначає зміну свідомості. Імерсивний досвід $є$ водночас символічним і фізичним: активно залучається сучасним театром (і імерсивним, й академічним), успішно реалізує потреби людини в самозаглибленні, чуттєвості, тілесності, в утвердженні себе як гармонійної особистості. На засадах методологічних рефлексій сучасної філософії проаналізовані теоретичні основи пізнання імерсивного досвіду шляхом вивчення ідей Е. Берна, Ж. Бодріяра, Й. Гейзінги, Ж. Делеза, Ж. Дерріда, Ж. Лакана, М. Мерло-Понті, зазначено продуктивність долучення до аналізу ритуального (ігрового) та релігійного досвіду. Розкрито концептуальні смисли імерсивних практик, які в контексті плюралістичної дійсності формують основи розвитку холістичного підходу до розуміння людської ідентичності, відтворення реальності в нових формах інтелекту, почуттів і творчості. Розвиток цілісного підходу до розуміння ідентичності людини шляхом формування імерсивного досвіду сприяє глибинним трансформаціям творчого потенціалу особистості. Досліджено формування особливого ставлення до життя на основі відкритості, «занурення», інтерсуб’єктивності та тілесності з залученням досвіду імерсивних практик.

Ключові слова: мистецькі стратегії; імерсивність; імерсивний досвід; імерсивні практики; відкритість; тілесність; інтерсуб'єктивність; імерсивний театр

\title{
Вступ
}

У сучасному соціокультурному просторі утворюється антропологічна реальність, яка формує новітні мистецькі стратегії. Вони є живим і унікальним досвідом творчості, відкритості, незавершеності та водночас відповідальної участі людини у визначенні майбутнього. Звернення науковців, експертіваналітиків, міжнародних організацій до проблем розвитку креативної культури та креативної економіки наразі є відчутним і актуальним. Відповідні теоретичні напрацювання має сучасна філософія, культурологія, соціологія, психологія. 
У філософській думці розвивається холістична парадигма мислення, яка сприяє подоланню культурної ізоляції та стимулює до перебування в стані потоку як творчого пошуку та перманентного становлення. Взаємодія філософії та мистецтва в контексті формування цієї парадигми набуває нових сенсів та віднаходить нові форми, використовуючи технічні та технологічні можливості, які експоненціально накопичують свій потенціал.

Постнекласичні практики як пошук новітніх форм взаємодії філософії та мистецтва 3 використанням цифрових можливостей безпосередньо взаємодіють з культурним модусом афтер-постмодерну, важливою рисою якого є особливе переживання синергії цілого і частини, реального та віртуального світів. Шляхом до розуміння підгрунтя цих процесів є вивчення імерсивності, яка постає не лише як характеристика взаємодії з віртуальним світом, але і як технологія та стратегія соціокультурного досвіду.

Аналіз останніх досліджень і публікаиій. Дослідження імерсивного досвіду у найрізноманітніших середовищах упродовж останніх років $є$ предметом вивчення у науковій літературі. Зокрема, S. Hogarth, E. Bramley, T. Howson-Griffiths аналізують імерсивні світи мистецьких перформансів та виконавчих практик (Hogarth та ін., 2018), J. Tepperman, M. Cushman вивчають досвід канадського імерсивного театру Brantwood (Tepperman \& Cushman, 2018), сенсорний лабіринтний театр та його місце в історії імерсивних театрів є предметом розгляду Т. Howson-Griffiths (Howson-Griffiths, 2020), імерсивний досвід у театрі є предметом найбільшої уваги науковців (Васильєв та ін., 2018), але репрезентація імерсивності як стратегії формування досвіду в інших середовищах також вивчається. Т. Кузілова (2021) описує досвід впровадження імерсивних технологій в роботі бібліотек, О. Кирилова (2020) вивчає перспективи вітчизняної імерсивної журналістики, М. Смульсон, В. Депутат та О. Іванова (Смульсон та ін., 2018) досліджують використання можливостей віртуального простору в освітніх цілях, В. Терещук (2016) аналізує можливість використання імерсивного досвіду в навчальному середовищі тощо. Маємо зауважити, що аналіз філософських засад цього досвіду ще не був предметом вивчення, а отже, такі напрацювання $є$ особливо актуальними. Наявний імерсивний досвід сучасного театрального мистецтва в контексті реалізації ним новітніх мистецьких стратегій також потребує вивчення та систематизації, а теоретичні та методологічні основи його культурфілософських рефлексій - повного та всебічного осмислення.

\section{Мета статті}

Мета статті - розкрити полісемантичність поняття «імерсивність»; проаналізувати наявний імерсивний досвід сучасного театрального мистецтва в контексті реалізації ним нових мистецьких стратегій; визначити та опрацювати теоретичне та методологічне підгрунтя імерсивності як нового поняття в сучасній естетиці, філософії мистецтва та філософії культури.

\section{Виклад матеріалу дослідження}

Розвиток сучасної науки та перманентне вдосконалення новітніх технологій сприяли формуванню та стрімкому розвитку цифрової реальності. Новостворений світ стрімко увійшов в життя людини та долучився до формування простору сучасної культури. Поруч із реальним світом формується низка реальностей, які треба диференціювати та ідентифікувати. Відтак, у сучасному культурологічному, мистецькому, естетичному та філософському дискурсі формуються поняття «real reality» (справжній, реальний світ), «augmented reality» (світ доповненої реальності), «mixed/hybrid) reality» (світ змішаної/ гібридної реальності), «virtual reality» (віртуальна реальність), «extended reality» (розширена реальність) та інші. Ознайомлення з особливостями кожної із реальностей дає можливість чітко окреслити простір та специфіку їхнього існування і реалізації. Світ доповненої реальності (augmented reality) поєднує предмети реального світу та створені з допомогою комп'ютерних технологій предмети; світ змішаної чи гібридної (mixed/hybrid reality) - у режимі реального часу через злиття реального та віртуального світів створює новий простір; світ віртуальної реальності (virtual reality) формує іншу, повністю змінену реальність, яка імітує справжню. Врешті, як наслідок, формується розширена реальність (extended reality) - простір, який ще очікує на ретельне вивчення та систематизацію.

Основою взаємодії людини із цифровим світом у різноманітних формах його прояву є «імерсія» своєрідне «занурення» в хронотоп цифрової реальності, яке стимулює людину до фізичного, тактильного, діяльнісного контакту із новітньою реальністю. Взаємодія із цифровим простором новітньої реальності не завжди $€$ «імерсивною». Вона набуває імерсивного характеру тоді, коли взаємодія грун- 
тується на взаємопроникненні світу цифрової реальності та внутрішнього світу людини, на залученні всіх рівнів сприйняття, створенні тілесного контакту та можливості максимально повного занурення людини в цифровий простір, де межі між реальностями стерто.

Сучасні форми імерсивного досвіду мають досить широкий спектр інтерпретацій. Найчастіше до змісту цього досвіду включають занурення у віртуальну реальність 3 допомогою сучасних IT-технологій. Проте детальніше дослідження цього питання виявляє й інші аспекти, що пов'язані здебільшого з формуванням внутрішнього досвіду, а ніж із використанням зовнішніх ефектів.

Слово «immersive» в англомовній літературі вживається переважно як частина словосполучень, у яких розкриваються такі його семантичні значення: 1) «to immerse yourself in something» — занурюватися у щось; 2) «to immerse oneself» чи «to be immersed» — втягувати себе в якусь дію; 3) «immersive experience» — iмерсивний досвід, тобто досвід, який людина отримує залученням в якусь дію (Cambridge University Press, n.d.); 4) «study format» - метод вивчення чогось через повне занурення, наприклад, іноземної мови з використанням виключно цієї мови. Якщо під «імерсією» розуміють власне стан занурення, то термін «імерсивний» розкриває, як відбувається залучення всіх почуттів та формується особливий досвід.

Варто зауважити, що протягом останнього десятиліття поняття імерсивності частіше трапляється в теоретичних працях, спрямованих на розкриття мистецького досвіду. Найбільше прикладів реалізації ефекту «занурення» ми спостерігаємо у кіномистецтві, театральному мистецтві, віджей-арті, перформансах, а також у віртуальній комунікації. Відтак саме театральне та кінематографічне середовище $є$ базовим для вивчення цього феномену. Насамперед поняття імерсивності («занурення») використовується не лише для визначення стилю виконання, але й для опису сучасних соціокультурних практик для заглиблення в «інший світ».

Процес розгортання імерсивного дійства в сучасному театрі формує глядача як учасника креативної взаємодії людей, що спільно створюють і переживають разом, кожен у свій унікальний спосіб, певну історію чи подію. Пошуки наперед не відомих рішень призводять до різноманітних інтерпретацій, що засвідчують унікальність досвіду кожного. Подібне радикальне зміщення відносин переформатовує аудиторію, сцену, глядача, виставу: концептуально, просторово і фізично. Аудиторія, яка прагне емоційних і тактильних вражень, активно залучається до спілкування та фізичної взаємодії. Пошук нових засобів «залучення» зумовлює появу нових форм імерсивних практик.

Театральне мистецтво постійно розвивається і дуже чутливо сприймає перехід від вербальності до образності та калейдоскопічності.

Пошук форми спектаклю, у якому глядач із пасивного спостерігача перетворюється на активного учасника творчого процесу, котрий поєднаний з актором та сценою, тривав упродовж XX століття. Теоретичні та практичні напрацювання А. Арто, Р. Болеславського, П. Брука, Б. Брехта, Л. Курбаса, В. Меєргольда, К. Станіславського, Л. Страсберга та інших класиків театрального мистецтва першої половини ХХ ст. мали вплив на творчі пошуки сучасних театральних режисерів: А. Варсімашвілі, Р. Віктюка, А. Жолдака, Е. Някрошюса, Р. Шехнера та ін.

Художній синтез, якого шукають через спільно з глядачами створюване дійство, постає як результат безпосередньої зустрічі «Я» 3 навколишнім світом (де «Я» — це актор, а «світ» — це глядач, але глядач i актор постійно обмінюються ролями, а перманентним учасником їхнього діалогу є широкий соціокультурний контекст від давнини до сьогодення). Театр у різноманітних формах синтезує, а також стає майданчиком неповторного феноменологічного досвіду переживання буттєвої цілісності та діалектичної єдності наявного, усуває розрив об'єктивного і суб'єктивного, зовнішнього і внутрішнього, а також допомагає зрозуміти активність внутрішнього. Саме за таких умов і виникає сучасний імерсивний театр, який допомагає максимально залучати у творчу взаємодію глядача. В такому театрі відбувається безпосередня фізична взаємодія глядача з іншою реальністю, що наближає імерсивний театр до інших форм сучасних культурних практик: кіно, телебачення, перформансу, відеоігор тощо.

Поняття «імерсивний театр» широко використовується, як науковцями, так і театральними критиками, від 2007 року для позначення напряму перформансу. Таку назву отримали театралізовані інтерактивні постановки в музеях за участі запрошених акторів, під час яких відвідувач ставав активним учасником імпрези. Функціонують різні види імерсивного театру: театр-енвайронмент, який зорієнтований на занурення глядача в штучно створене середовище; театр-мандрівка чи променад, що пропонує максимально наближену до реальності мандрівку; до різновидів імерсивного театру належать також вистави-аудіотури, спектаклі-виставки, квести; як самостійний різновид виділяють VR-театр: він створює вистави із використанням різноманітних пристроїв (наприклад, шоломи чи окуляри доповненої реальності) для створення віртуальної реальності. 
Нині лідером інновацій із впровадження імерсивних практик є Велика Британія: «Dreamthikspeak», «Punchdrunk», «Shunt», - найвідоміші театральні колективи. Їхні постановки досліджували Дж. Мейхон (Machon, 2013), А. Алстон (Alston, 2016) та ін.

Рух у напрямку створення імерсивного театру активно триває в Україні. У сучасному українському театрі відбувається «зміна лідерів театрального процесу», і як наслідок - побудова нових комунікативних та менеджерських стратегій, створення нового «театрального продукту». Вітчизняні театри все більше зацікавлені у залученні нової аудиторії, яка прагне саморозвитку, тому постійно оновлюють репертуар (Васильєв та ін., 2018). До українського імерсивного театру можна зарахувати колективи: ЦСМ «Дах», «Чорний квадрат», «Мізантроп», «UZAHVATI» та інші.

Сучасний нелінійний стиль мислення мають як митці Центру сучасного мистецтва «Дах» (засновник В. Троїцький), так і їхня цільова аудиторія. Постійні глядачі театру прагнуть нових відкриттів, зрушень у власному сприйнятті, трансформації внутрішніх процесів, їх не влаштовує просте сприйняття творчого продукту.

Принципом «живої» акторської гри вирізняється театр-студія «Чорний квадрат» (засновник А. Нейолов). Кожна вистава «народжується тут і зараз». Актори безпосередньо залучають глядача до дійства, ведуть діалог з глядачем перед спектаклем, а потім органічно використовують його у виставі. Часто актори грають безплатно, а після вистави обговорюють сюжет із глядачами.

Інтерактивний київський театр «Мізантроп» (засновники I. Мощицький та Д. Саратський) створює виставу «Дуб Майкла Крейг Мартіна» (режисер I. Мощицький), у якій немає акторів, декорацій та навіть сценарію. Актори обираються серед глядачів. В основі спектаклю лежить п’єса Т. Крауча та філософський твір Г. Дебора «Суспільство спектаклю», навколо роздумів над цими творами під час самої вистави формується жива сценічна дія.

Від 2016 року команда українського театру «UZAHVATI» (засновники П. Бараніченко, О. Орловський, О. Стужук) також створює імерсивні вистави. Відбуваються вони в різних місцях: в бібліотеках, на стадіонах, під час прогулянок Києвом. Такі вистави завжди дарують відчуття невизначеності та невідомості, оскільки ні маршрут, ні локацію глядач заздалегідь не знає. Наприклад, у виставі «Dialogy» (режисер П. Бараніченко) 20 глядачів створюють власні 20 особливих історій, що стають способом самопізнання, занурення кожного у свій внутрішній світ. Глядач протягом цього часу переживає зовсім несподівані емоції. Кожна постанова як інструмент самопізнання і для глядача-учасника, $\mathrm{i}$ для режисера-постановника.

Імерсивні практики не є продуктами конструювання митців на запит сьогодення, вони виникають як відповідь на потреби сучасної людини. Театр постає майданчиком віднайдення нової інтеграційної цілісності в сучасному світі. Повертаючи людині тілесність, чуттєвість, він повертає їй віру у себе та власні сили, підвищує самооцінку, долає «капсульність» як (вимушену чи набуту) форму існування. Театр також набуває ознак місця інтелектуальних пошуків сьогодення та способу реалізації філософських ідей. А саме - подивитися на себе з несподіваного ракурсу, переосмислити життєвий досвід та світоглядні засади, відчути власну синкретичну єдність зі світом, віднайти шляхи реалізації холістичних ідей. Парадигматика сучасних театрів постійно змінюється під впливом віртуального мистецтва, філософських дискурсів та цифрових технологій. Все частіше людину прагнуть вивести із «зони комфорту», спонукають активно взаємодіяти з реальним життям, що сприяє міжособистісній взаємодії та самоусвідомленню.

До таких інноваційних творчих практик вдаються не лише новітні імерсивні, але й академічні театральні колективи. Долучають імерсивність як засіб творення художнього простору у постановках провідних українських академічних театрів, зокрема у Національному академічному драматичному театрі ім. І. Франка (режисери П. Богомазов, С. Мойсеєв, Д. Петросян, І. Уривський), Київському академічному театрі на Подолі (режисери С. Жирков, В. Малахов, С. Павлюк), Івано-Франківському національному академічному драматичному театрі ім. І. Франка (режисер Р. Держипільский), Херсонському обласному академічному музично-драматичному театрі ім. М. Куліша (режисери О. Книга, С. Павлюк), Одеському академічному музично-драматичному театрі ім. В. Василька (режисери М. Голенко, І. Уривський).

Теоретичні засади пошуків в імерсивному театрі закладені філософією, естетикою та культурологією XX ст. Широке застосування імерсивного досвіду потребує детального вивчення його теоретичного підгрунтя та аналізу того культурфілософського контексту, котрий уможливлює різноманітне та всебічне його впровадження. Вивчення екзистенційно-феноменологічного, новітніх та архаїчних форм ритуального (ігрового) та релігійного досвіду, аналіз вживаних філософських концептів сьогодення 
(«симулякр», «ризома», «слід», «стадія дзеркала» та ін.), вивчення певних філософських праць та аналіз філософського доробку представників сучасного філософування є напрямками пошуку теоретично-методологічних засад імерсивності.

Р. Вагнер свого часу шукав шляхи створення універсального художнього твору («Gesamtkunstwezk»), який долає розірваність деяких різновидів мистецтв. Ідею «тотального мистецтва» (spectacle total) пропонував впровадити французький драматург, режисер та філософ А. Арто (2000). У праці «Театр жорсткості» теоретик театру пише: «Ми хочемо відродити ідею, взяти у кінематографа, мюзиклу, цирку та самого життя все, що споконвіку належить театру. Розкол між аналітичним театром і пластикою нам завжди видавався дурницею. Не можна відділити ні дух від тіла, ні почуття від розуму, тим більше коли в результаті постійної перевтоми органи чуттів потребують різкого струсу, щоб відновити свою здатність до сприйняття» (Арто, 2000, с. 178).

Музика Р. Вагнера мала значний вплив як на мистецтво, так і на філософію XX ст.: Ф. Ніцше, для прикладу, шукає шляхи до поєднання аполлонівського і діонісійського начал в культурі для відновлення iї повноти. Теорія, яку розвивав А. Арто, надихала театральних експериментаторів в 60-ті роки XX ст., зокрема, Р. Шехнера.

Теоретичне підгрунтя для вивчення імерсивності в контексті пізнання новітніх взаємодій у найширшому розумінні цього поняття сформували ідеї екзистенційно-феноменологічної філософії М. Мерло-Понті. Основною темою філософії М. Мерло-Понті є взаємодія людини і світу. Запозичене ним із феноменології поняття феномену використовується для фіксації унікального способу буття суб'єктивності у світі. Світ, про який розмірковує філософ, це світ людської культури та міжособистісної взаємодії. Взаємодія людини і світу нерозривно пов'язана з взаєминами між людьми, з тим, що в філософських дослідженнях називають інтерсуб'єктивністю. Світу в його антропологічному вимірі немає «самого собою», а у сприйнятті і через сприйняття іншим, сприймається «мною» лише тоді, коли має місце його сприйняття «іншим» (Мерло-Понти, 1996).

Своєрідність філософської концепції М. Мерло-Понті полягає в тому, що філософ, вважаючи феномен «первинним відкриттям світу», роль суб'єкта в цьому процесі відводить людському тілу, що $\epsilon$ неначе речником буття у світі, стрижнем, завдяки якому світ набуває можливості бути олюдненим, лише через тіло світ дістає нагоду бути втіленим. М. Мерло-Понті використовує означення «вісь» для визначення ролі, яку відіграє людське тіло в реалізації можливостей людини пізнати світ та поєднатися 3 ним. Тіло як суб'єкт сприйняття має специфічне значення: воно $є$ продовженням світу, складається 3 тієї ж плоті, що й світ, тіло є водночас «мірою всього», «універсальним вимірювачем». Навіть у первинному сприйнятті, де «сприйняття» $\mathrm{i}$ «досвід свого тіла» проникають одне в одне, тіло здійснює свою функцію суб' єкта - виступає диференційованою єдністю, завдяки чому спонтанне сприйняття (хаос, що сприймається чуттєво) також постає цілісністю. Саме завдяки тілу людина проникає в світ, розуміє його і надає йому значення, вона сприймає світ усім своїм тілом як відкритою цілісністю, - вважав М. Мерло-Понті (Мерло-Понти, 1996). Первинне сприйняття є основою, на якій зростають всі людські смисли та значення. Емпіричне підтвердження цієї думки закладають розроблення гештальт-психологів. Кожний індивід має власну реакцію на все навколо, на ії основі він створює свої змісти, які з використанням можливостей тіла транслює іншим. Тіло індивіда неначе передає іншим індивідам деякий імпульс, що походить від світу та проходить через певного індивіда. Така ланцюгова реакція пов'язує людей з буттєвими началами, що передаються під час безпосереднього контакту, тілесно. «Інший» постає для індивіда як істота одного роду, яка захоплює його і ним захоплена в спільному намірі освоєння єдиного та спільного буття.

Імерсивний досвід апелює до первинного емоційного феномену та має ігрову природу. Й. Гейзінга (1994) у книзі «Ноmo Ludens» («Людина, що грає») визначає головні модуси гри, яка містить у собі глибинну буттєву природу становлення: добровільність; наявність чітких правил, але і гнучкість їхнього застосування; створення свого віртуального світу з власними правилами, формування свого образу чи моделі; деяка сакральність, утаємниченість та винятковість; змагальність, але не обов'язковість, добровільність, можливість виходу з неї та їі зупинки у будь-який момент; визначеність у часі та просторі; вмотивованість гри нею самою; брак у грі наміру переслідувати будь-які інші, ніж вона сама, цілі; зорієнтованість гри на відтворення (наближення) світу духовних змістів, формування таких змістів, їхня трансляція як носіїв інформації в певному культурному просторі. Е. Берн (2016) у творі «Ігри, у які грають люди» виокремлює в житті людей кілька наскрізних рольових середовищ, в межах яких вони реалізують себе в ігровій формі та пропонує вийти за межі цих ігор через пробудження автономії власного «Я» та спрямування його до створення простору вільної гри на основі близьких емпатичних стосунків. 
Дж. Вітмор (Whitmore, 1996), в контексті розуміння «ігрової природи» особистості наголошує на тому, що людям потрібно допомогти віднайти «їхню власну внутрішню гру». Мається на увазі, що в процесі навчання, творчості, життя загалом потрібно відходити від процесу та технології «вдосконалення майстерності» і діяти по-іншому — вдосконалювати власну сутність. Він зазначає, що це стосується свідомості, духу і тіла. Кожна людина, на його думку, у цьому пошуку має знайти взаємозв'язок зі своїм власним ритмом.

Ігровий складник імерсивних практик здебільшого розкривається через залучення до його вивчення релігійного досвіду, метою якого $є$ через культові дії долучити індивіда до особистісного глибокого контакту з трансцендентним. Дуже часто елементом таких релігійних практик $є$ тілесний контакт з його носієм. Р. Біггін (Biggin, 2017) коріння імерсивних практик вбачає в баптистському ритуалі повного занурення у воду. Вивчення архаїчного релігійного досвіду та його відтворення в культурних артефактах сьогодення $\epsilon$ ще одним джерелом для вивчення форм сучасного імерсивного досвіду.

Розширенням джерельної бази дослідження імерсивності є залучення до вивчення цього поняття філософських концептів, що міцно увійшли в сьогодення не лише як маркери сучасного мистецтва, а як наскрізні риси його культурфілософського контексту. Зокрема, таких, як: «симулякр» (Бодріяр, 2004), «ризома» (Deleuze \& Guattari, 1980), «слід» (Деррида, 2012), «стадія дзеркала» (Лакан, 1999). «Симулякр» позначає водночас і втрату реальності, і створення нової гіперреальності, яка максимально відчутна і тотально присутня. «Ризома» $є$ шляхом до розуміння її будови та принципів функціонування, відкритих, не лінійних, фрактальних. «Слід» фіксує глибинну сутність праджерела, яка наявна у всьому, він провідник між глибинними онтологічними змістами та сьогоденням, він тому постає як те, що маркує віртуальний ландшафт, формує його принципову незавершеність, відсилаючи водночас до реального та трансцендентного. «Стадія дзеркала»є моделлю водночас і процесу самопізнання, і конструювання власної ідентичності через опосередкований контакт з відображенням реального світу. Визначені поняття не є лінійними, тому можуть бути залучені і для пояснення інших денотативних змістів імерсивності. 3 огляду на синкретичність (імерсивний досвід символічний, ментальний, і фізичний водночас), вона потребує актуалізації засобами, що придатні до відтворення синкретичного змісту.

У сучасному світі зростає попит на імерсивність, тож актуальність ії вивчення зростає. Встановлені теоретичні джерела імерсивності мають бути доповнені додатковим аналізом певних праць як філософського, так і мистецького спрямування.

\section{Висновки}

Поняття «імерсивність» має широкий полісемантичний сенс, в основі якого лежить фіксація досвіду «занурення», що створюється переважно з залученням можливостей цифрової реальності. Імерсивні практики не є результатом технічних експериментів митців, вони реалізують потреби сучасної людини, для якої все відчутнішою стає актуальність тілесного досвіду, «занурення» в ситуацію і відчуття своєї фізичної присутності у світі. Під час дослідження проаналізовано наявний імерсивний досвід сучасного театрального мистецтва в контексті реалізації ним новітніх мистецьких стратегій.

Імерсивність розкрито як спосіб сприйняття, що визначає зміну свідомості; зазначено, що імерсивний досвід $є$ як символічним, так і фізичним. В імерсивних практиках аудиторія активно залучається до фізичної взаємодії та спілкування, здобуває нові можливості самоусвідомлення та впровадження змін. Бажання пошуку нових способів взаємодії та «залучення» еволюціонує в розвиток нових форм імерсивних практик. Майданчиком інтеграції в сучасному світі та місцем інтелектуальних пошуків сьогодення у напрямку реалізації холістичних засад $є$ сучасний театр, який виявляє потреби людини у поверненні до самої себе, самозаглибленні, чуттєвості, тілесності, утвердженні себе як особливої та впевненої особистості, здатної гармонійно взаємодіяти зі світом.

Філософські ідеї Е. Берна, Ж. Бодріяра, Й. Гейзінги, Ж. Делеза, Ж. Дерріда, Ж. Лакана, М. Мерло-Понті розглянуто як теоретично-методологічне підгрунтя виявів імерсивності в сучасному мистецтві. Здійснено аналіз ритуального (ігрового) та релігійного досвіду як джерела вивчення імерсивності. Перспективу подальших досліджень має сформувати глибший аналіз філософських засад імерсивного досвіду шляхом залучення ширшого кола філософських праць.

Формування цілісного підходу до розуміння ідентичності людини, який сприяє глибинним трансформаціям творчого потенціалу особистості, розглянуто в контексті пошуку нових форм інтеграції інтелекту та почуттів як стратегії розвитку мистецтва XXI століття. 


\section{Список використаних джерел}

Арто, А. (2000). Театр и его двойник: Манифестыл. Драматургия. Лекиии. Философия театра (В. Максимов, О. Кустова, Г. Смирнова, \& А. Зубков, пер.). Симпозиум.

Берн, Е. (2016). Ігри, у які грають люди (К. Меньшикова, пер.). Клуб Сімейного Дозвілля.

Бодріяр, Ж. (2004). Симулякри і симуляиія (В. Ховхун, пер.). Основи.

Васильєв, С., Чужинова, І., Соколенко, Н., Салата, О., Тукалевська, О., \& Жила, В. (2018). Украӥнський театр: илях до себе. Здобутки. Виклики. Проблеми. Культурна Асамблея. http://nstdu.com.ua/wp-content/uploads/2019/02/ Doslidjennya_UKR_PDF_Final.pdf

Гейзінга, Й. (1994). Ното Ludens (О. Мокровольський, пер.). Основи.

Деррида, Ж. (2012). Поля философии (Ю. Кралечкин, пер.). Академический Проект.

Кирилова, О. В. (2020). Українські перспективи імерсивної журналістики. Communications and Communicative Technologies, 20, 49-55. https://doi.org/10.15421/292007

Кузілова, Т. М. (Уклад.). (2021). Імерсивні технології в роботі бібліотек для дітей. Національна бібліотека України для дітей. https://cutt.ly/7EZHtDZ

Лакан, Ж. (1999). Семинары. Книга 2: «Я» в теории Фрейда и в технике психоанализа (А. Черноглазов, пер.). Гносис; Логос.

Мерло-Понти, М. (1996). В защиту философии (В. Вдовина, пер.). Издательство гуманитарной литературы.

Смульсон, М. Л., Депутат, В. В., \& Іванова, О. В. (2018). Психологічні умови розвитку суб’єктної активності у віртуальному просторі на прикладі дистанційного курсу. Technologies of intellect development, $2(9)$. https://doi.org/10.31108/3.2019.2.9.1

Терещук, В. (2016). Віртуальне навчальне середовище: сутність та психолого- педагогічні умови його створення. Науковий вісник Ужгородського національного університету. Серія: Педагогіка. Соиіальна робота, 1, 279-283.

Alston, A. (2016). Making Mistakes in Immersive Theatre: Spectatorship and Errant Immersion. Journal of Contemporary Drama in English, 4(1), 61-73. https://doi.org/10.1515/jcde-2016-0006

Biggin, R. (2017). Immersive Theatre and Audience Experience: Space, Game and Story in the Work of Punchdrunk. Palgrave Macmillan. https://doi.org/10.1007/978-3-319-62039-8

Cambridge University Press. (n.d.). Immerse. In Cambridge Dictionary. Retrieved June 14, 2021, from https://dictionary. cambridge.org/dictionary/english/immerse

Deleuze, G., \& Guattari, F. (1987). A Thousand Plateaus: Capitalism and Schizophrenia (B. Massumi, Trans.). University of Minnesota Press. (Original work published 1980).

Hogarth, S., Bramley, E., \& Howson-Griffiths, T. (2018). Immersive worlds: an exploration into how performers facilitate the three worlds in immersive performance. Theatre dance and performance training, 9(2), 189-202. https://doi.org $/ 10.1080 / 19443927.2018 .1450780$

Howson-Griffiths, T. (2020). Locating sensory labyrinth theatre within immersive theatres' history. Studies in theatre and performance, 40(2), 190-205. https://doi.org/10.1080/14682761.2019.1663649

Machon, J. (Ed.). (2013). Immersive Theatres: Intimacy and Immediacy in Contemporary Performance. Palgrave Macmillan. https://doi.org/10.1017/S0040557415000423

Tepperman, J., \& Cushman, M. (2018). BRANTWOOD: Canada's Largest Experiment in Immersive Theatre. Canadian theatre review, 173, 9-14. https://doi.org/10.3138/ctr.173.002

Whitmore, J. (1996). Coaching for Performance (2 ${ }^{\text {nd }}$ ed.). N. Brealey Pub.

\section{References}

Alston, A. (2016). Making Mistakes in Immersive Theatre: Spectatorship and Errant Immersion. Journal of Contemporary Drama in English, 4(1), 61-73. https://doi.org/10.1515/jcde-2016-0006

Arto, A. (2000). Teatr i Ego Dvoinik: Manifesty. Dramaturgiya. Lektsii. Filosofiya Teatra [Theatre and Its Double: Manifestos. Dramaturgy. Lectures. Theatre Philosophy] (V. Maksimov, O. Kustova, G. Smirnova, \& A. Zubkov, Trans.). Simpozium [in Russian].

Baudrillard, J. (2004). Symuliakry i Symuliatsiia [Simulacra and Simulation] (V. Khovkhun, Trans.). Osnovy [in Ukrainian].

Berne, E. (2016). Ihry, u Yaki Hraiut Liudy [Games People Play] (K. Menshykova, Trans.). Klub Simeinoho Dozvillia [in Ukrainian].

Biggin, R. (2017). Immersive Theatre and Audience Experience: Space, Game and Story in the Work of Punchdrunk. Palgrave Macmillan. https://doi.org/10.1007/978-3-319-62039-8 
Cambridge University Press. (n.d.). Immerse. In Cambridge Dictionary. Retrieved June 14, 2021, from https://dictionary. cambridge.org/dictionary/english/immerse

Deleuze, G., \& Guattari, F. (1987). A Thousand Plateaus: Capitalism and Schizophrenia (B. Massumi, Trans.). University of Minnesota Press. (Original work published 1980).

Derrida, J. (2012). Polya Filosofii [Margins of Philosophy] (Yu. Kralechkin, Trans.). Akademicheskii Proekt [in Russian].

Hogarth, S., Bramley, E., \& Howson-Griffiths, T. (2018). Immersive Worlds: an Exploration into How Performers Facilitate the Three Worlds in Immersive Performance. Theatre Dance and Performance Training, 9(2), 189-202. https://doi.org/10.1080/19443927.2018.1450780

Howson-Griffiths, T. (2020). Locating Sensory Labyrinth Theatre within Immersive Theatres' History. Studies in Theatre and Performance, $40(2), 190-205$. https://doi.org/10.1080/14682761.2019.1663649

Huizinga, J. (1994). Homo Ludens (O. Mokrovolskyi, Trans.). Osnovy [in Ukrainian].

Kuzilova, T. M. (Comp.). (2021). Imersyvni Tekhnolohii v Roboti Bibliotek dlia Ditei [Immersive Technologies in the Work of Libraries for Children]. National Library of Ukraine for Children. https://cutt.ly/7EZHtDZ [in Ukrainian].

Kyrylova, O. V. (2020). Ukrainski Perspektyvy Imersyvnoi Zhurnalistyky [Ukrainian Perspectives Of Immersive Journalism]. Communications and Communicative Technologies, 20, 49-55. https://doi.org/10.15421/292007 [in Ukrainian].

Lacan, J. (1999). Seminary. Kniga 2: "Ya" v Teorii Freida i v Tekhnike Psikhoanaliza [Seminars. Book 2: The Ego in Freud's Theory and in the Technique of Psychoanalysis] (A. Chernoglazov, Trans.). Gnosis; Logos [in Russian].

Machon, J. (Ed.). (2013). Immersive Theatres: Intimacy and Immediacy in Contemporary Performance. Palgrave Macmillan. https://doi.org/10.1017/S0040557415000423

Merleau-Ponty, M. (1996). V Zashchitu Filosofii [In Defense of Philosophy] (V. Vdovina, Trans.). Izdatel'stvo Gumanitarnoi Literatury [in Russian].

Smulson, M. L., Deputat, V. V., \& Ivanova, O. V. (2018). Psykholohichni Umovy Rozvytku Subiektnoi Aktyvnosti u Virtualnomu Prostori na Prykladi Dystantsiinoho Kursu [Psychological Conditions of the Subjectness Activity Development in Virtual Space at the Example of the Distance Course]. Technologies of Intellect Development, 2(9). https://doi.org/10.31108/3.2019.2.9.1 [in Ukrainian].

Tepperman, J., \& Cushman, M. (2018). BRANTWOOD: Canada's Largest Experiment in Immersive Theatre. Canadian Theatre Review, 173, 9-14. https://doi.org/10.3138/ctr.173.002

Tereshchuk, V. (2016.). Virtualne Navchalne Seredovyshche: Sutnist ta Psykholoho- Pedahohichni Umovy Yoho Stvorennia [Virtual Learning Environment: the Essence and Psychological and Pedagogical Conditions of Its Creation]. Naukovyi Visnyk Uzhhorodskoho Natsionalnoho Universytetu. Seriia: Pedahohika. Sotsialna Robota [Scientific Bulletin of Uzhhorod University. Series: Pedagogy. Social Work], 1, $279-283$ [in Ukrainian].

Vasyliev, S., Chuzhynova, I., Sokolenko, N., Salata, O., Tukalevska, O., \& Zhyla, V. (2018). Ukrainskyi Teatr: Shliakh do Sebe. Zdobutky. Vyklyky. Problemy [Ukrainian Theatre: the Way to Yourself. Achievements. Challenges. Problems]. Kulturna Asambleia. http://nstdu.com.ua/wp-content/uploads/2019/02/Doslidjennya_UKR_PDF_Final. pdf [in Ukrainian].

Whitmore, J. (1996). Coaching for Performance (2 $2^{\text {nd }}$ ed.). N. Brealey Pub.

Стаття надійшла до редакиії: 01.10.2021

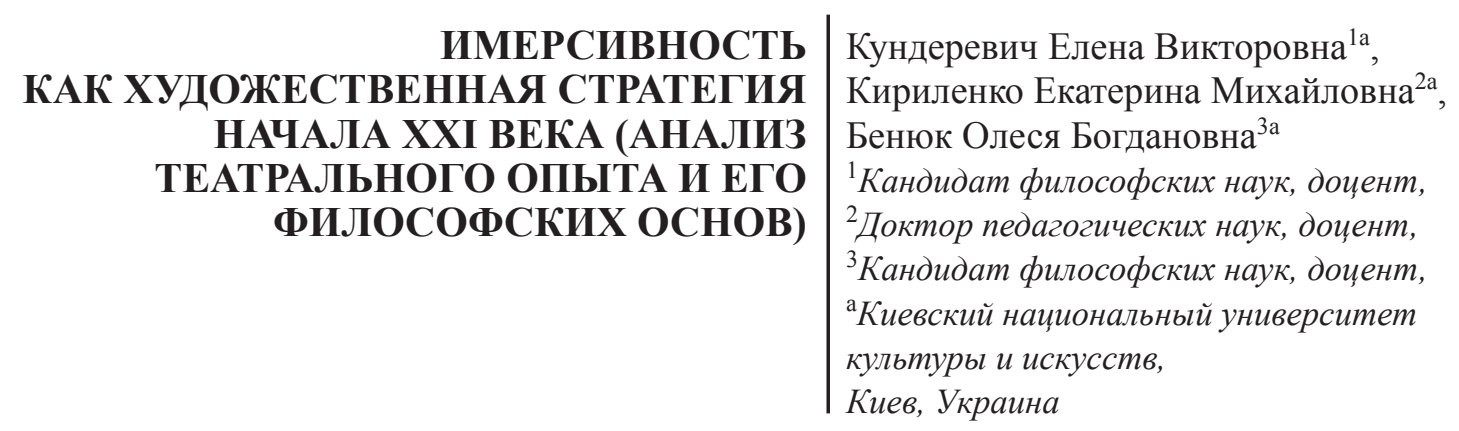

Цель статьи - раскрыть полисемантичность понятия «имерсивность»; проанализировать имеющийся иммерсивный опыт современного театрального искусства в контексте реализации им новейших художественных стратегий; определить и проработать теоретическое и методологическое основание имерсивности как нового понятия 
в современной эстетике, философии искусства и философии культуры. Методологию исследования сформировали методы эмпирического (наблюдения, сравнения, мониторинга) и теоретического исследования (междисциплинарного анализа, конкретизации, абдуктивного рассуждения). Выводы. На основе сочетания эмпирического и теоретического методов осуществлен анализ трансформационного потенциала иммерсивных практик. Предоставлено более широкую экспликацию таким понятиям, как «имерсивность», «иммерсивные практики», «иммерсивный театр». Установлено теоретические основы исследования культурфилософских основ имерсивности. Выяснено, что имерсивность является способом восприятия, который определяет изменение сознания. Иммерсивный опыт является одновременно символическим и физическим: активно привлекается современным театром (и иммерсивным, и академическим), успешно реализует потребности человека в самоуглублении, чувственности, телесности, в утверждении себя как гармоничной личности. На основе методологических рефлексий современной философии проанализированы теоретические основы познания иммерсивного опыта путем изучения идей Э. Берна, Ж. Бодрийяра, И. Гейзинги, Ж. Делеза, Ж. Деррида, Ж. Лакана, М. Мерло-Понти, указано производительность добавления к анализу ритуального (игрового) и религиозного опыта. Раскрыто концептуальные смыслы иммерсивных практик, которые в контексте плюралистической действительности формируют основы холистического подхода к пониманию человеческой идентичности, воспроизведение реальности в новых формах интеллекта, чувств и творчества. Развитие целостного подхода к пониманию идентичности человека путем формирования иммерсивного опыта способствует глубинным трансформациям творческого потенциала личности. Исследовано формирование особого отношения к жизни на основе открытости, «погружения», интерсубъективности и телесности с привлечением опыта иммерсивных практик.

Ключевые слова: художественные стратегии; имерсивность; иммерсивный опыт; иммерсивные практики; открытость; телесность; интерсубъективность; иммерсивный театр

\begin{tabular}{r|l} 
IMERSIVENESS & Olena Kunderevych ${ }^{1 \mathrm{a}}$, \\
AS THE TWENTY-FIRST-CENTURY & ${\text { Kateryna Kyrylenko }{ }^{2 \mathrm{a}},}$, \\
ART STRATEGY (ANALYSIS & Olesia Beniuk ${ }^{3 \mathrm{a}}$ \\
OF THEATRE EXPERIENCE & ${ }^{1}$ PhD in Philosophy, Assistant Professor, \\
AND ITS PHILOSOPHICAL BASES) & ${ }^{2} D S c$ in Education, Assistant Professor, \\
& $\begin{array}{l}{ }^{3} P h D \text { in Philosophy, Assistant Professor, } \\
{ }^{\mathrm{a}} \text { Kyiv National University of Culture and Arts, } \\
\text { Kyiv, Ukraine }\end{array}$
\end{tabular}

The purpose of the article is to reveal the polysemantic concept of immersiveness; to analyse the existing immersive experience of contemporary theatrical art providing the art strategies; to define and work out the theoretical and methodological basics for immersiveness as a new concept in contemporary aesthetics, philosophy of art and philosophy of culture. The research methodology was formed by empirical methods (observation, comparison, monitoring) and theoretical research (interdisciplinary analysis, concretisation, abductive inference). Conclusions. Based on a combination of empirical and theoretical methods, the transformation potential of immersive practices was analysed. A broader explication of such concepts as immersiveness, immersive practices, the immersive theatre was given. Theoretical basis of research of cultural-philosophical foundations of immersiveness was established. It was found that immersiveness is a way of perception that determines the change in consciousness. An immersive experience is both symbolic and physical. It is actively used by contemporary theatre (both immersive and academic), which implements the human's need to return to self-absorption, sensuality, corporeality, asserting oneself as a special and moral human being. Based on methodological reflections of contemporary philosophy, the theoretical foundations of cognition of immersive experience are analysed by studying the ideas of E. Bern, J. Baudrillard, J. Huizinga, G. Deleuze, J. Derrida, J. Lacan, M. Merleau-Ponty, the productivity of involvement of philosophical reflections of ritual (game), and the religious experience was demonstrated. The authors reveal the conceptual meanings of immersive practices, which form the basis for the development of a holistic approach to understanding human identity, the reproduction of reality in new forms of intelligence, feelings and creativity in the context of pluralistic reality. The development of a holistic approach to understanding human identity through immersive experience contributes to the profound transformations of the individual's creative potential. The formation of a special attitude to life based on openness, immersion, intersubjectivity and corporality with the involvement of the experience of immersive practices has been studied.

Keywords: art strategies; immersiveness; immersive experience; immersive practices; openness; corporeality; intersubjectivity; immersive theatre 